\title{
Using the Critical Management Studies tenet of denaturalisation as a vehicle to decolonise the management discourse in South Africa
}

\section{Author:}

Prof. Geoff A. Goldman ${ }^{1,2}$

\section{Affiliation:}

${ }^{1}$ Department of Business Management, University of Johannesburg, South Africa

${ }^{2}$ Department of International Management, Krakow University of Economics, Poland

E-mail:

ggoldman@uj.ac.za

DOI:

10.15249/14-1-272

Keywords:

critical management studies; decolonisation; denaturalisation; emancipation; Jacques Rancière

\section{Abstract}

It has been roughly five years since the \#FeesMustFall student protests shook the foundations of higher education in South Africa. However, in the aftermath of these protests, students' demand for the decolonisation of the curriculum, despite initial energy, has seemingly lost momentum. Within the discipline of management and organisation studies, the situation is even more exacerbated, with efforts towards decolonisation being cosmetic at best. However, much criticism has been directed towards the notion of decolonisation for its lack of normative literature. This article suggests that Critical Management Studies (CMS) and, in particular, the CMS notion of denaturalisation, might provide a broad framework for achieving decolonisation. Furthermore, the work of contemporary philosopher Jacques Rancière is proposed as a pragmatic means to denaturalise management thinking to move closer to a truly decolonised management curriculum in South Africa.

\section{Introduction}

In 2015, students across South Africa protested against the state of higher education in the country. In what would later be known as the \#FeesMustFall campaign, students demands centred around a call for state-subsidised higher education; alleviation of student debt; the insourcing of outsourced labourers; accelerated affirmative action measures amongst academic staff; and the so-called "decolonisation of the curriculum" (Knight \& Goldman, 2016). From an academic point of view, the call for decolonised education is of particular interest. For the vast majority of students, higher education in 
South Africa was still very much 'colonial', and still reflected a very Western-centric way of thinking, with little or no regard for African knowledge and indigenous knowledge systems.

This call for decolonised education forced South African higher education institutions to do some introspection in terms of the knowledge that it was creating and disseminating to students. Indeed, in the years after the \#FeesMustFall protests, decolonisation became part of the institutional agenda at many universities in South Africa. The institutional expectation was that decolonisation would be driven at faculty and departmental level and the call for decolonised and transformed curricula heeded.

It is now almost five years since the \#FeesMustFall movement made the demand for a more transformed higher education system, and yet the tempo thereof seems to be painstakingly slow; even to the point where very little real progress towards a decolonised curriculum has been made.

This article postulates that a contributing factor in the slow pace and superficial progress made in the decolonisation project is that academics differ on what is meant by decolonisation. In many instances, there is a total misconception, even no conception, as to what decolonisation is; exacerbating efforts to promote and work towards a decolonised curriculum.

The article further suggests that the critical management studies (CMS) tenet of denaturalisation can be used as a tool to work towards a decolonised curriculum. The argument is presented that decolonisation, at its core, represents a contextualised and somewhat politicised version of postcolonial discourse. As post-colonialism is a recognised area of application in organisation theory and CMS (Jack \& Westwood, 2006; Johnson \& Duberley, 2003), it would be a logical extension to suggest that decolonisation can be seen as a form of critical enquiry, and can therefore benefit from a concept borne out of critical inquiry.

The article is structured, as follows, to elucidate the arguments suggested above: Firstly, an overview is presented of the discourse around decolonisation since 2015. From this overview, challenges associated with decolonisation in the South African context will be highlighted. Thereafter, the discussion will hone into the unique challenges to decolonisation in the discourse of management. After that, a link between decolonisation and post-colonialism will be established; followed by a discussion focussed on denaturalisation and how it can be employed as a tool for striving for a decolonised management education curriculum.

\section{The discourse surrounding decolonisation post-\#FeesMustFall}

Although student protests calling for a reconsideration of South African higher education are not a new occurrence in South Africa (Fomunyam, 2017a), the \#FeesMustFall protests of 2015 and 2016 saw an unprecedented revival of students airing their dissatisfaction 
with the slow pace of transformation in South African higher education. These protests represent the most important student uprising since 1976 (Muswede, 2017).

The \#FeesMustFall student protests that started in October 2015 and continued well into 2016 saw the resurgence of calls for decolonised education at South African higher education institutions. The student organisations made it blatantly clear that society demanded an immediate and radical rethink of the South African education system (Rahlaga, 2015). Furthermore, the majority of the South African population, due to the legacy effects of both colonial rule and apartheid, have always felt estranged from the very education system that was supposed to benefit them (Nkomo, 2011).

Fundamentally, the call for decolonised education centres around the point that since moving into a democratic, all-inclusive political dispensation in 1994, colonial and apartheid legacies are perpetuated in many areas of South African society (Nwadeyi, 2016). These protests, and their precursors over time, represent a revolt against structural disenfranchisement that a large part of the South African populace experienced and embody a need for fair and equal access to opportunities that have the potential to improve their lives (Disemelo, 2015).

Decolonisation embodies more than merely replacing the apartheid era and the colonial era symbols and increasing the number of black academics and local texts in the curriculum (Prinsloo, 2016). The essence of decolonisation involves a rebuff of the centrality of the 'West' in the African understanding of itself and Africa's place in the world, with the aim of re-centring around Africa, both intellectually and culturally (Mbembe, 2015; Ngugi wa Thiong'o, 2004). Frantz Fanon, a scholar, widely embraced by the \#FeesMustFall movement, envisages decolonisation as a process of remaking, which is often violent to create new humanity (Fanon, 1963). Thus, decolonisation requires that one reconceptualises the purpose of the university in the African context. We need to reinvent, from an African perspective, what a university is all about and whom it is for (Collini, 2012; Mbembe, 2015; Prinsloo, 2016). To achieve this, it is, therefore, crucial to understand the effect of the 'traditional South African university' (being a 'Western' university) and the knowledge it generates in the African context. Crucial here is considering how this generated knowledge influences and sanctions thinking and behaviour towards 'others' (referring to those groupings of society not catered for in 'Western' thinking) (Pillay, 2015). This situation embodies the very disenfranchisement that the \#FeesMustFall movement was rebelling against.

The dominantly Western, Eurocentric canon that pervades academia in South Africa, therefore, needs to be interrogated, and the involvement of this Euro-centricity in side-lining the epistemic traditions endemic to Africa needs to be understood. If this Eurocentric pervasiveness in South African academia is downplayed, the struggle that African epistemic traditions need to endure to obtain any form of legitimacy and voice equity, will never fully be appreciated and recognised. Therefore it is important to explore how the legacy effects of both colonialism and apartheid continue to influence and shape not only South African society in general, but in particular practices, values, and agendas in South African universities (Langdon, 2013; Prinsloo, 2016) 
In terms of the resurgent call for decolonisation, this revolt is an appeal to end white, Western, Global 'North' supremacy that is prevalent in South African higher education (Fomunyam, 2017a; Garuba, 2015; Zembaylas, 2018), and to promote indigenous knowledge and (South) African epistemologies, experiences and thought in the curricula in higher education institutions in South Africa (Heleta, 2016). It would seem as though this Western supremacy is exclusionist towards epistemologies and knowledge systems that are not Western, white, or from the Global North, and treats these as inferior (Mgqwashu, 2016). Thus, decolonisation is a call for the recognition that South African universities are centred in Africa and should therefore be Afrocentric. In so doing, South African universities should recognise, give voice to, and promote African epistemologies and knowledge systems that promote African interests. This recognition will contribute to greater inclusivity in a country where the majority of people feel alienated in the classroom (Le Grange, 2016). However, it needs to be recognised that the debates and discussions entered into about decolonisation represent an uncomfortable space, and they are difficult for those who take part in them (Le Grange, 2016; Prinsloo, 2016).

Literature consulted on the issue of decolonisation from 2015 onwards (in other words, after the \#FeesMustFall protests started), suggests that the pace of decolonisation efforts is slow (Heleta, 2016). However, transformative efforts in higher education in South Africa, in general, has been very slow (Fomunyam, 2017; Muswede, 2017; Zembaylas, 2018). Reasons purported for the 'snail's pace' of transformation in this sector include a lack of resources made available by the government for transformation, differing institutional understandings, and differing levels of willingness to transform. This slow pace of transformation exacerbates the situation even further and leaves South African higher education in a very tense state.

\section{Decolonisation and the South African management discourse}

Decolonisation efforts in the management sciences have, in my view, been exceedingly slow. However, I believe that the lack of pace of decolonisation in the management sciences is no surprise, as business and management represent a very colonially ubiquitous domain. The pervasiveness of the capitalist doctrine in business, organisation and management studies is so immense that it leaves virtually no room for the conceptualisation of anything that represents a divergence from it. Management as an academic discipline can also be seen as a continuation of the colonial project (Jack $\&$ Westwood, 2006). As a field of enquiry, mainstream management discourse strives for universality and supports the unity of science notion, and in so doing, marginalises non-Western traditions (Goldman, 2016b). This situation has to be seen as part of the larger project of Western capitalism. As with any ideology, structures, institutions and mechanisms are created to perpetuate and entrench the ideology. In the case of business management as an academic discipline, the capitalist ideology created business schools, management courses and business faculties to promote and perpetuate the ideology of 
capitalism. It can, therefore, be opined that all South African management scholars can be seen as proponents of the Western, capitalist doctrine, to a lesser or greater degree (Maserumule, 2015).

Given the pervasiveness of this Western capitalist doctrine, the probability that people that have been schooled in this tradition will be susceptible to alternate conceptions of business and management is slim. This situation seems to be even more pronounced in South Africa, as the apartheid legacy attempted to follow in the wake of the colonial legacy by upholding many of the values that colonialism advocated (Heleta, 2016). However, decolonisation as a scholarly project requires that business and management academics be open to notions of business and management that fall outside that purported by the mainstream (i.e. capitalist inspired) thinking. Coupled with institutional expectations that decolonisation be driven at faculty and department level (i.e., by academics), the paradox here is quite obvious: Decolonisation of business management is driven by academics whom themselves struggle to abstract alternative notions of business and management.

The logical consequence of the paradox outlined in the previous paragraph is that management academics' reactions to heed the call for a decolonisation of the discourse will be varied. These reactions vary from a total misconception about what decolonisation is and what it entails, to a flawed understanding of the concept; 'making light' of the decolonisation project; superficiality in addressing decolonisation; or a total refusal to explore the possibilities decolonisation presents.

I am certain that not all management scholars are in the position I was in, to be exposed to the liberal arts in the form of philosophy, and therefore most management scholars, in my experience, do not venture further than the parameters of the management body of knowledge. This situation reminds strongly of the notion of the 'business school mentality' that Goldman, Nienaber and Pretorius (2015) purport. This 'business school mentality' implies that management as an academic discipline is preoccupied with equipping people with the requisite skills for the working world, rather than placing emphasis on shaping well-rounded people for a career in management. Thus, the emphasis is on vocational, competency-based training at the expense of 'liberal' education focusing on cognitive development and the promotion of critical thinking skills, which enable problem-solving and innovation (Mentz, Kotze \& van der Merwe, 2008). This emphasis on vocationalism weakens an appreciation for the epistemic foundation of management amongst management scholars (Goldman et al., 2015).

The question of vocationalism is not new to the management education discourse, dating back to the critique of the notion of vocationalism in business schools in the late 1950s (Gordon \& Howell, 1959; Pierson, 1959). Despite systemic and individual efforts to address this in the 1960s, very little seems to have been done since to address this issue (Wren \& Bedeian, 2009). As a result, management education emphasises skill and celebrates the experiences of successful businesspeople and under emphasises the theoretical and epistemological foundations of the discipline. This thinking leaves no scope for re-examining the modus operandi of seemingly successful business practices. 
The outcome of this situation is that issues such as power imbalances, distributive justice, workplace fairness, emancipation and oppression, ethics, and epistemology profoundly lack in mainstream management discourse (Goldman et al., 2015).

Against this backdrop, it is understandable that management academics will face challenges in their understanding of decolonisation as well as their reaction to decolonisation. In my experience, management scholars conceive of, and react to, decolonisation in one of two ways:

- They incorporate more local examples and local case studies into their teaching and learning activities.

- They prescribe local content (i.e. textbooks, journal articles, and conference proceedings) for syllabi.

While these steps are viewed as a point of departure, it is debatable whether they represent efforts at decolonisation at all. Although it can be argued that such efforts represent the incorporation of local knowledge into syllabi, it can also be argued that these steps denote nothing more than 'candy coating', avoiding the real issues associated with decolonisation (Garuba, 2015), and 'ticking the boxes' to satisfy heads of departments and deans of faculty. These efforts do not critically question and challenge the fundamental ontological and epistemic assumptions that management education is premised upon, it is merely perpetuating the prevalent ontological and epistemic assumptions underlying the mainstream (or 'colonised') management discourse and education. Heleta (2016) mentions that this approach is followed at South African universities in the majority of academic disciplines. True decolonisation demands that scholars understand the underlying ontological and epistemological assumptions that the management discourse is based on, that one critically examines and challenges these assumptions. If it is found that these assumptions do not fit the South African context, these assumptions need to be rejected, and scholars should seek to replace them with more relevant assumptions.

Sceptics might be quick to ask what should be done if 'colonised' assumptions do not fit our context, but there is nothing more relevant to replace them with. Such a reaction could be seen as an unwillingness to actively seek marginalised points of view and indigenous knowledge and promote these to a point where they enjoy legitimacy in the management discourse. The marginalisation and subjugation of local knowledge systems and epistemologies, coupled with relatively low literacy rates in Africa means that indigenous knowledge is mainly contained in an oral tradition, with very little documented in a formal body of knowledge. This situation should not be forwarded as an excuse to perpetuate current academic norms, values, and practices. It should rather be seen as presenting real opportunity to shape alternative points of view and knowledge systems.

Instead, the 'nothing to replace it with' argument should be seen as a call to action; the perfect opportunity for scholars to start documenting what has, up to now, largely been undocumented wisdom encapsulated in an oral tradition. What is being presented here is the opportunity for management scholars to actively seek the uniquely African 
snippets, contributions, stories, and experiences that, over time, could inspire a body of knowledge representing African management thinking and discourse.

At the same time, it should also be stressed that the 'nothing to replace it with' argument, as well as decolonisation efforts in themselves, cannot, and should not, attempt to discard or vilify the mainstream (and per implication 'colonised') body of management knowledge. From a critical scholarship point of view, one cannot be critical of something if one does not have an understanding of what this 'something' is. If one recognises that decolonisation is a critical endeavour in itself, it is, therefore, necessary to know and understand the mainstream, colonised doctrine before one can attempt to challenge the underlying ontological and epistemic assumptions of the mainstream. Successful and meaningful decolonisation, therefore, requires us to embrace the mainstream, colonised conception of the discipline of management, and not to reject it in totality.

Within the management discourse, it is imperative that scholars embark on efforts understand the underlying ontological and epistemological assumptions that the management discourse is based on, and that they start challenging these assumptions to further the decolonised agenda. The question, however, is how can this be done in the discipline of management? In this regard, CMS and the CMS tenet of denaturalisation offer some respite, in my view.

\section{Critical management studies and decolonisation}

As I have already alluded to, the decolonisation debate (in the context of management) fits perfectly into the critical management studies (CMS) discourse. At this juncture, it might be prudent to elaborate a little on this connection.

CMS, an emergent project within the broader management discourse, views management as a persuasive discourse emanating from the ideological tenets of capitalism (Sułkowski, 2019). Management, as a discourse, attempts to maintain the capitalist status quo through dominance and exploitation. CMS aims to subvert this status quo through interrogation of the seemingly objective and accepted aspects of organisational functioning, such as organisational hierarchy, managerial practices, organisational power relations, and organisational conduct (Alvesson \& Willmott, 2003). Thus, CMS is highly sceptical of mainstream management thinking, as well as the epistemological foundations thereof (Goldman, 2016b). It wants to demonstrate how management practice and research has been fixated on organisational performance at the expense of societal welfare, and what the implications of this fixation are (Adler, Forbes \& Willmott, 2007; Prasad \& Mills, 2011). CMS rejects the political and historical neutrality that pervades mainstream management thinking and accepts a value-laden reality (Goldman, 2016a). As such, CMS creates scope for alternative epistemologies that are concerned with novel methodologies of knowledge production.

CMS thus views the mainstream management as an instrument of domination, inequality, and subjugation, which serves to enforce and maintain the doctrine of 
capitalism. However, the CMS project is not merely concerned with exposing these notions of inequality and domination. As a movement which has gained momentum in (especially) Europe (Prasad \& Mills, 2011), it seeks to promote the search for a better organisational future. Thus, the notion of emancipation is of prime importance to CMS, for without action for an emancipatory purpose, CMS will be meaningless (Bridgman \& Stephens, 2008).

The fit, between decolonisation and CMS, is evident from the following points:

- South Africa decolonisation stems from a basic dissatisfaction with the slow pace of change that has characterised South African higher education since 1994. CMS similarly reflects a basic dissatisfaction with mainstream management thinking and how it perpetuates injustices associated with capitalism. Thus, both decolonisation and CMS embody dissatisfaction with a prevalent and pervasive status quo; perceived to be flawed and perpetuating injustices.

- Decolonisation represents a revolt against the centrality of the 'West' in the African understanding of the world and Africa's place in the world. CMS, in turn, revolts against the oppression and inequality that management enact under the auspices of the capitalist ideology. Thus, both CMS and decolonisation represent a revolt against the current status quo, which at times, is bound to cause unease and discomfort, as it demands radicalisation of both thought and action.

- Decolonisation envisions a future 'ideal' state, where Africa is at the centre of the African understanding of the world. In this sense, there is an emancipatory angle to decolonisation, as it strives to create conditions for the attainment of certain freedoms; echoing the CMS ideal of a search for a better organisational future. Furthermore, both CMS and decolonisation recognise that this emancipation will entail struggle, in one form or another, against the dominant status quo in its quest for emancipation. Thus, emancipation is a central theme in both CMS and decolonisation.

- The decolonisation discourse criticises Eurocentric epistemic processes as being discriminatory and marginalising the epistemic traditions favoured in the African context. In much the same way, CMS rejects knowledge claims based purely on the application of the scientific method at the expense of the values that underlie them. Thus, both CMS and decolonisation question the legitimacy of dominant epistemologies and methodologies of knowledge creation and promote the utilisation of different approaches to knowledge creation in the creation of more legitimate knowledge.

- Decolonisation requires that academics question and interrogate the basic assumptions that their respective disciplines are based upon and question the legitimacy of these assumptions in the (South) African context. If these assumptions are found wanting, they need to be replaced by more legitimate assumptions. In the CMS context, the basic assumptions of capitalism are constantly interrogated, and their legitimacy constantly questioned. Thus, CMS and decolonisation are not normative discourses. They do not seek to establish 'rules' to conform with, but rather they seek to explore possibilities of what is possible and attainable. 
From the preceding discussion, it can be seen that there is a definite fit between decolonisation and CMS. Table 1 provides a summary of this fit between decolonisation and CMS.

Table 1: Dimensions of overlap between decolonisation and CMS

\begin{tabular}{|l|l|l|}
\hline \multicolumn{1}{|c|}{ Dimension } & \multicolumn{1}{|c|}{ Decolonisation } & \multicolumn{1}{c|}{ CMS } \\
\hline $\begin{array}{l}\text { Dissatisfaction with the } \\
\text { perpetuation of injustice. }\end{array}$ & $\begin{array}{l}\text { Dissatisfied with the slow pace of } \\
\text { transformation in South African } \\
\text { higher education. }\end{array}$ & $\begin{array}{l}\text { Dissatisfied with the perpetuation } \\
\text { of exploitative practices associated } \\
\text { with capitalism. }\end{array}$ \\
\hline $\begin{array}{l}\text { Revolt against prevalent } \\
\text { status quo. }\end{array}$ & $\begin{array}{l}\text { Revolt against the centrality of the } \\
\text { 'West'. }\end{array}$ & $\begin{array}{l}\text { Revolt against managerialist } \\
\text { subjugation. }\end{array}$ \\
\hline Envisioning emancipation. & $\begin{array}{l}\text { Africa is central to its understanding } \\
\text { of the world. }\end{array}$ & Better organisational future. \\
\hline $\begin{array}{l}\text { Questioning dominant } \\
\text { epistemologies. }\end{array}$ & $\begin{array}{l}\text { Eurocentric epistemologies are } \\
\text { discriminatory and marginalising. }\end{array}$ & $\begin{array}{l}\text { Epistemologies of capitalism } \\
\text { are too reliant on scientific method } \\
\text { at the expense of underlying values. }\end{array}$ \\
\hline Non-normative discourse. & $\begin{array}{l}\text { Questions the underlying } \\
\text { assumptions of the curriculum, not } \\
\text { methods of teaching. }\end{array}$ & $\begin{array}{l}\text { Questions the underlying } \\
\text { assumptions of capitalism, not } \\
\text { methods of organisational efficiency. }\end{array}$ \\
\hline
\end{tabular}

From Table 1, one can deduce that in terms of certain dimensions, CMS is decolonisation. As CMS stands in opposition to capitalism, a product and continuation of European imperialist expansionism and colonialism (Banerjee \& Linstead, 2001; Linstead, Marechal \& Griffin, 2014), it represents a decolonised position as such. Similarly, decolonisation is part of the critical discourse, stemming from a subjugated populace's dissatisfaction against a dominant and unjust status quo with the end goal of creating a new, egalitarian order. Furthermore, the dimensions identified in the discussion above and contained in Table 1 can also be seen as the dimensions that need to be addressed to decolonise the management discourse in South Africa.

Having established this connection between CMS and decolonisation, it would be logical to ask how CMS could assist in striving for decolonised education in South Africa? To answer this question, we first need to turn to the three central tenets of CMS, namely anti-performativity, reflexivity, and denaturalisation (Fournier \& Grey, 2000).

The first tenet of CMS, 'anti-performativity' suggests that business management knowledge should not be used exclusively to further a managerialist agenda. Mainstream management views knowledge as a tool to pursue the effectiveness of managerial practice. The anti-performative stance questions this and suggests that management knowledge should rather be used to address issues of inequality, dominance, and oppression in the organisational context to create a better form of organisation (Butler \& Spoelstra, 2014; Fournier \& Grey, 2000). The issue of anti-performativity is contested in the CMS discourse, with divergent views on the topic. The second of these tenets, 'reflexivity' recognises the values which direct CMS research agendas, as well as the epistemic principles that guide this research. CMS scholars reflect more on the assumptions and routines of knowledge creation and understand how culture, history and context influence knowledge, and what the consequences thereof are (Butler \& Spoelstra, 2014; Goldman, 2016b). The final tenet, 
'denaturalisation', suggests that CMS scholars do not accept management knowledge at face value. Instead, they seek out the embedded institutionalised notions within permeate the mainstream discourse and questions the legitimacy of the assumptions they are based on (Fournier \& Grey, 2000; Goldman, 2016a).

It is the tenet of denaturalisation that we now turn our attention to, as I believe that this principle has vast application, and relevance, in the decolonisation debate.

\section{Unpacking 'denaturalisation'}

This CMS tenet reflects the scepticism towards the mainstream management discourse that is ingrained in the CMS project as a critical endeavour. Denaturalisation urges scholars not to accept knowledge at face value, but rather to challenge the ideological foundations thereof and to expose any anomalies that might arise. Meticulous denaturalisation has the potential to unearth and promote alternative points of view that the pervasive, mainstream management discourse hitherto marginalised or stifled (Butler \& Spoelstra, 2014).

Denaturalisation, therefore, represents an innate stance of 'not taking anything for granted', and constantly questions principles of the object under investigation. In a certain sense, denaturalisation demands of critical scholars to 're-problematise' phenomena, thereby exposing the inherent ontological and epistemic orientations, interests, values, and motivations that gave rise to the contemporary conceptions of these very phenomena (Jack \& Westwood, 2006). This thorough scrutiny that denaturalisation demands also has the potential to uncover the underlying historical, cultural and ideological contexts of these phenomena. In a sense, denaturalisation is a mechanism to 'upset the apple cart' of the image of coherence that exists in the mainstream conception of business and management. This upset is established by identifying claims and incidences that casts uncertainty over this perceived coherence (Prasad \& Mills, 2011). On an epistemological level, denaturalisation casts light on how some business and management discourses and methodologies are favoured and enjoy privilege while others are marginalised or relegated to the periphery (Grey \& Willmott, 2005; Prasad \& Mills, 2011),

The connection between denaturalisation and decolonisation should be apparent. Denaturalisation offers a lens through which management scholars can re-problematise the basic assumptions of the colonised, mainstream management discourse and epistemologies of knowledge creation. It offers the opportunity to engage with these concepts critically and propose new assumptions if the current assumptions have no claims to legitimacy in the African context. Then, denaturalisation is proposed as a vehicle to achieve decolonisation in the academic discipline of management.

However, the same problem is encountered when viewing denaturalisation as is encountered when one confronts the issue of decolonisation. Although literature purports many points of view on, and references to, what decolonisation and denaturalisation entail, virtually nothing exists regarding normative suggestions on how to decolonise or denaturalise. Especially as far as decolonisation is concerned, this presents a major 
stumbling block in the journey towards decolonised education in South Africa, as the practical implications are still unclear as far as pedagogy and research are concerned (Govender, Heyneke, Mntambo \& Goldman, 2018).

Thus, in the absence of any normative debate or practical advice on either decolonisation or denaturalisation, the work of French philosopher Jacques Rancière might provide some clarity on the question of 'how'. As indicated, this article proposes that denaturalisation be employed as a vehicle in the pursuit of decolonisation in management discourse. Therefore, the work of Rancière will be engaged to suggest a more pragmatic view to denaturalisation.

Jacques Rancière is best known for his work on ideology and working-class identity, although the idea of emancipation pervades his work (Huault, Perret \& Spicer, 2014). It is his ideas on emancipation that will be engaged with here, as I believe that Rancière's conception of emancipation resounds with the notion of denaturalisation. One might ask how ideas on emancipation will inform pragmatism towards denaturalisation, but this becomes clear if one equates the notion of being denaturalised to the notion of attaining freedom. Freedom can be perceived as a particular capacity or 'state of being'. It is thus an end in itself, which involves acts and processes of 'making free'. Thus, if being free (i.e. freedom) is the result, the end state, then the activities and processes associated with seeking freedom denote the realm of emancipation (Blauner, 1964). Hence, if freedom is the end, then emancipation is the means to that end. The link between freedom and emancipation should also be apparent. In the context of denaturalisation, being denaturalised, or developing denaturalised management knowledge, would entail acts and processes of denaturalisation. Denaturalisation is, therefore, how denaturalised management knowledge is sought. Thus, the result is being denaturalised (possessing denaturalised knowledge); the 'state of being'; the freedom attained. Denaturalisation is the emancipatory means by which this freedom is achieved. This line of reasoning leads one to conclude that 'being denaturalised' is freedom, while 'denaturalisation' is emancipation.

In Rancière's conception of emancipation, three ideas stand out, achieving equality, creating dissensus, and reshaping the 'distribution of the sensible' (Huault et al., 2014). These will briefly be expounded upon.

\subsection{Achieving equality}

For Rancière, any form of social inquiry needs to start with a basic acceptance of the notion of equality amongst humans, as opposed to inequality between them (Huault et al., 2014). This viewpoint does not imply that he ignores or downplays the inequalities and exploitative forces that characterise organisational life. Rather, he asserts that these are forces that create inequality and that if these forces are not present, equality exists amongst people. Equality is, therefore, something that needs to be asserted within society. Rancière is adamant that equality is not an ideal consigned to the future, but an imperative, a founding premise, that needs to be actualised in the present (Badiou, 2006). 
Where inequality is prevalent, emancipation thus involves enforcing the idea of equality as something that is not utopian but innate (Rancière, 1987). As opposed to most emancipation-oriented organisation studies, premised in inequality between people in the organisational context, Rancière rejects the notion that their hierarchical position determines people's potential and that they are thus diminished to structural positions and roles (Huault et al., 2014). In other words, Rancière is at loggerheads with the notion of voluntary servitude, where the dominated workers are estranged from the management elite, does not know what is oppressing them or why, and therefore resigns to his fate (Costas \& Fleming, 2009). Rancière believes that the dominated are very aware of their subjugation, and that emancipation does not start with having this exploitation being revealed to them (Rancière, 2006). Instead, Rancière suggests that the dominated need to attain a vision of themselves beyond the domination they find themselves in, which can only be achieved by foregoing certain necessities that keep them 'in their place' (Huault et al., 2014).

For Rancière, emancipation does not come about through actions of the 'enlightened scholar' that sensitises the dominated to their subjugation and mediates a vision of a better future state (Alvesson \& Willmott, 1992; Huault et al., 2014). Rather, it comes from trusting the intellectual capability of the dominated. It, therefore, involves learning to become equal in an unequal world (Rancière, 2009a).

\subsection{Creating dissensus}

Rancière further suggests that the politics of emancipation are not based on collective opinions of consensus, but rather occur with an expression of dissensus (Rancière, 1995). He challenges the argument that emancipation comes about through the notion of 'collective deliberation', which contests that emancipation is the result of finding common ground, thus involving negotiation and agreement (Dryzek, 2002). Rancière takes a distinct turn away from the 'collective deliberation' principle and argues that emancipatory politics do not involve reaching consensus, but rather that it involves a distinct breaking of consensus (Rancière, 2009b). In his conception of emancipatory politics, Rancière purports that achieving consensus results in nothing more than pacification, which represses emancipation. Rather, emancipation requires challenges to the consensus that dominant groupings define; challenges that these groupings perceive as acts of conflict (Rancière, 1998).

The idea of creating consensus can be seen as a movement towards a zone of comfort, where the creation of consensus implies that people are sheltered from discomfort. In stark contrast, the idea of breaking consensus, and thus creating dissensus, involves moving out of one's comfort zone. For Rancière, dissensus involves deliberately experiencing discomfort and lament. It is, according to Rancière, in this process of struggle where the moment and experience of emancipation is encountered (Huault et al., 2014). 
A third point Rancière purports on emancipation is what he refers to as a 'reconfiguration of the share of the sensible' (Rancière, 2004; Rancière, 2009a). This reconfiguration implies turning to marginalised claims and discourses and interrogating these against what is understood to be sensible. In so doing, the parameters and substance of what can be perceived as sensible and conceptualised within the sensible are reconfigured. This reconfiguration comes about when assumed shared understandings of what is known and possible and conditions leading to shared understanding are contested and disrupted (Huault et al., 2014). To fully understand this notion, it is necessary to understand what Rancière means by 'the sensible' itself.

Rancière's conception of what he terms 'the sensible', can best be understood if one thinks of 'the sensible' as a system. This system contains certain knowledge that legitimises our point of view about a particular aspect of reality and the possibilities associated with it. However, this system also contains norms and values that act as parameters for what the system deems legitimate. Furthermore, the system also consists of role players that subscribe to the norms and values of the system, Some of these role players are not very visible, but others are visible, and through their engagement with the system, they help define the norms and values of the system (Rancière, 2004).

Thus, to achieve emancipation, Rancière purports that what is needed is a reconfiguration of this system of the sensible. This reconfiguration would assume the guise of a fundamental shake-up of this system (Ruby, 2009), for example, occurring when issues previously deemed irrelevant to the sensible or marginalised by it, now become issues of importance, or when people that previously played no part in the sensible become prominent role players in the system and are now deemed to be of importance to the sensible. The net effect thereof is that the norms and values that define the parameters of the sensible are now altered to accommodate these new issues or people with their points of view (Huault et al., 2014).

However, the mere fact that once marginalised, or once irrelevant claims and people rise to importance within the sensible does not automatically mean that these will reconfigure, or claim a share of, the sensible. They do not, in other words, gain legitimacy just because they are there. They need to prove that they can contribute to what is known about, and what can be known about, the sensible (Calás \& Smircich, 2006). In other words, they need to prove that their reconfiguration of the sensible is in the best interest of the sensible; that it will work to the betterment of the sensible. This reconfiguration would imply critical reflection and questioning of ingrained ideas that emancipatory struggles and strugglers hold; and the outcomes they wish to achieve to ascertain if these struggles can contribute to the sensible at all, and (if they can contribute) which ideas and proponents are best suited to do so (Huault et al., 2014).

This section has unpacked the CMS concept of denaturalisation and has honed in on the work of Jacques Rancière as a possible way to view denaturalisation. The ensuing 
discussion will attempt to contextualise Rancière's work in terms of the concept of 'denaturalisation'; to provide pragmatic suggestions on how to pursue decolonisation within management scholarship and pedagogy.

\section{From Rancière to decolonisation through denaturalisation}

To apply the thoughts of Rancière to the notion of denaturalisation as a vehicle to decolonise management education in South Africa, one has to conceive Rancière's work in a somewhat novel way. Although Rancière's ideas on equality and emancipation apply to human beings as the subject of his work, the application to denaturalisation requires that one conceives this subject differently. Instead of human beings as the subject, I propose that knowledge claims should be seen as a specific dimension of the human subject for which equality is to be asserted and for which emancipation is sought.

By viewing knowledge claims as a dimension of the human subject upon which Rancière's thoughts are applicable, the discussion will proceed by imagining Rancière's three central emancipatory ideas as intellectual 'tools' to denaturalise management thinking. Before proceeding with the discussion, it is necessary to emphasise that 'knowledge claims' referred to in this discussion will imply management knowledge forthcoming from an intellectual process that is distinctly decolonised. Furthermore, the discussion views decolonisation as the desired end state; the freedom that is to be achieved through the emancipatory acts of denaturalisation. This view also implies that the end state might not be concrete, but rather an idealisation. In other words, the end state (in this case, decolonised management education) could be a state that can never be fully achieved, but rather one that scholars constantly strive for. An ideal that directs and necessitates constant reflection of the most salient tenets of the discourse as a whole.

In terms of Rancière's notion of achieving equality, scholars need to reflect upon and challenge their ontological assumptions. Scholars, as human subjects, cannot assert the equality of knowledge claims if they are not convinced of the legitimacy thereof. Scholars need to assume, and believe, that all knowledge claims are therefore innately equal and that inequality between different knowledge claims does not automatically exist because of the global origin of these claims or because of the epistemological foundations of such knowledge clams. Achieving equality, therefore, needs to begin in the belief systems of scholars themselves.

In the management discourse, for example, there is a long-standing debate raging in terms of the so-called 'paradigm wars' (Denzin, 2010), which represents a tension between positivist and social constructivist points of view. Although not as prevalent today, undertones of 'paradigmatic tension' still abound in management and organisation studies as a field of inquiry (Terrell, 2012). However, to denaturalise and achieve decolonisation, such tensions must be ceased. The constant bickering and posturing that takes place within the parameters of this 'paradigm war' is obstructionist and destructive to the progress of the scholarly project (Denzin, 2010). Although it is 
recognised that scholars are schooled in different traditions, scholars must acknowledge different scholastic traditions and learn more about them. It is also recognised that a scholar cannot be expected to know everything as far as methodological research issues are concerned. However, every discipline has a mainstream, dominant view, with a couple of peripheral views surrounding it. Management as a discourse, for example, is predominantly a positivist field of enquiry, but social constructivism and critical theory (in the form of CMS), are peripheral traditions in management. The point is that irrespective of which tradition scholars were schooled in, they must acquire some level of knowledge concerning all three traditions to contribute meaningfully to the discourse. If one does not carry any or sufficient knowledge about traditions outside of those you were schooled in, one will view all claims through one lens only, and one will not be able to conceive of all knowledge claims as equal.

As knowledge claims represent a dimension of the human subject, in this case, the scholar, the scholar acts as a 'champion' to contest the equality (and therefore legitimacy) of knowledge claims. Rancière is insistent that emancipation is not dependent upon the actions of a champion in the form of an enlightened scholar, but rather comes about through faith in the intellectual capability of the dominated, as detailed earlier in this article. The situation is, however, differ if one seeks emancipation for knowledge claims. The human subject - the scholar - can reason, and Rancière suggests that this capability needs to be utilised to learn to be equal in an unequal world. As knowledge claims are a dimension of the human subjects, these creators or proponents of knowledge claims need to take it upon themselves to assert the legitimacy of knowledge claims. This assertion is where the belief system of the individual scholar, outlined above, is of paramount importance. Scholars need to believe in the legitimacy of the knowledge claims they wish to assert equality upon, as the legitimacy they seek will not come automatically, but will have to be fought for. This struggle will have to take on the guise of active intellectual activism, where debates are entered into, and platforms are created to engage with these knowledge claims to assert this equality. If one acknowledges that emancipation involves struggle, then this is one of the struggles that knowledge claims, as a dimension of the human subject, will have to endure to assert their legitimacy.

In terms of translating Rancière's notion of creating dissensus to denaturalisation, this would require conscious and deliberate action on behalf of the scholar, as a champion of the knowledge claim, to openly challenge and disrupt mainstream, conventional thinking and create controversy. However, these actions should not be seen as being obstructionist and controversial just for the mere sake of being so. As denaturalisation and decolonisation's milieu is the realm of scholarship, the antagonist creating the dissensus should bear in mind that ultimately the end goal is to bring about a reconceptualisation of management as a discourse. Therefore, it is vital to realise that whatever dissensus is formed, the knowledge claim that is being championed must adhere to the principle of rigour. However, this is defined within the parameters of the epistemic tradition from where it hails. The human subject, the scholar, should stake his/her claim to be taken seriously by the rest of the scholarly community. 
As alluded to, creating dissensus requires deliberate action on the part of the creator of the knowledge claim. Such action could take many different forms, but the overriding principle here should be constant engagement with the mainstream convention on various platforms. 'Platforms' would refer to, for example, academic conferences, scholarly journals, scholarly books, workshops, colloquia, and other instances where scholarly output and intellectual material is showcased. Only through constant and persistent engagement can dissensus be created; not only entailing engagement via existing platforms but should also be sought in platforms that do not currently exist. Existing platforms are usually bastions of the mainstream convention, and therefore represents quite an unequal playing field if one wants to champion a view that challenges convention. It is necessary when addressing this inequality, to create new platforms that will be more susceptible to unconventional ideas. Again, this would require great personal effort and struggle on the part of the scholar.

Actions that lead to the creation of dissensus will, over time, create a situation where the knowledge claim becomes a peripheral point of view. It is under these conditions that the knowledge claim is now ready to claim a share of the sensible, and thereby reconfigure the share of the sensible, which is the third notion central to Rancière's conception of emancipation. As Rancière suggests, the sensible can only be reconfigured if a fundamental 'shake up' occurs within it. He continues by purporting that it is in the realm of marginalised claims and discourses that such shake-ups originate, as very often, such marginalised claims and discourses enter the sensible to a point where the sensible, as a system, can no longer ignore them.

Thus, once enough dissensus has been created and the system of the sensible, which in the context of this discussion is the mainstream management discourse and the associated scholarly community, can no longer ignore such knowledge claims, the reconfiguration of the sensible can commence. It is vital that this reconfiguration is conscious and planned. As the sensible contains norms and values acting as parameters of what the system deems legitimate or not, any reconfiguration of the sensible must involve a sense of knowing which of these norms and values are to be impacted and redefined and how. Ultimately, this redefinition of key norms and values upon which the sensible rests will redefine the parameters of what is deemed legitimate.

Returning to the example of the 'paradigm wars', it is apparent that the interpretive or social constructivist paradigm, which employs predominantly qualitative methodologies, has grown in prominence over the past two decades. However, this has not always been the case. Qualitative scholars have had to struggle for quite some time for legitimacy. In recent times, however, it has been recognised that qualitative research cannot be ignored, and management journals adverse to qualitative work now increasingly publish qualitative work. Conferences are more open to qualitative work, and more and more masters' and doctoral students are attempting qualitative studies in South Africa. Even certain prominent South African management scholars, who were once fervent opponents of qualitative scholarship and saw no legitimacy in it, have started to dabble in the realm of the qualitative. Thus, dissensus has been created, and the sensible could 
no longer ignore it and has subsequently embraced qualitative scholarship as equal to quantitative scholarship, thereby ensuring that qualitative scholarship has claimed a share of the sensible, and has reconfigured the sensible as a system.

However, this reconfiguration has occurred far too organically, in my opinion. Although the qualitative scholarship is burgeoning in South Africa, in many instances, there is insufficient understanding of the principles of the interpretive/social constructivist paradigm that is normally associated with qualitative methods. Thus, one finds a qualitative scholarship that is embarked upon from a quantitative and positivist frame of reference. The point is that not enough engagement has taken place between qualitative proponents and the system of the sensible in the form of debate through, inter alia, interpretive/social constructivist workshops, colloquia, and plenary sessions at conferences. Scholars have thus not consciously reshaped the boundaries of the sensible to include sufficient appreciation of the interpretivist/social constructivist paradigm. On the other hand, this situation might in itself lead to stimulating and emergent conceptions of what research could entail.

Table 2 below summarises the discussion presented above regarding how the end state of decolonisation in management education can be pursued by using the notion of denaturalisation. As discussed, in this sense, the three central notions of Rancerian emancipation philosophy are proposed as a guide to denaturalise.

Table 2: Denaturalising actions for decolonisation

\begin{tabular}{|l|l|l|l|}
\hline Assumptions & Asserting equality & Creating dissensus & $\begin{array}{l}\text { Reconfiguring the } \\
\text { sensible }\end{array}$ \\
\hline $\begin{array}{l}\text { Knowledge claim is } \\
\text { rigorous }\end{array}$ & $\begin{array}{l}\text { Reflect upon and } \\
\text { challenge own } \\
\text { ontological assumptions }\end{array}$ & $\begin{array}{l}\text { Deliberate action via } \\
\text { targeted, existing } \\
\text { platforms }\end{array}$ & $\begin{array}{l}\text { Conscious, deliberate } \\
\text { engagement with the } \\
\text { sensible }\end{array}$ \\
\hline $\begin{array}{l}\text { Knowledge claim has } \\
\text { decolonised value }\end{array}$ & $\begin{array}{l}\text { Champion knowledge } \\
\text { claims }\end{array}$ & $\begin{array}{l}\text { Create platforms to } \\
\text { showcase claims }\end{array}$ & $\begin{array}{l}\text { Engage with underlying } \\
\text { norms and values of the } \\
\text { sensible }\end{array}$ \\
\hline $\begin{array}{l}\text { Engagement by the } \\
\text { scholar }\end{array}$ & Intellectual activism & $\begin{array}{l}\text { Persevere until claims } \\
\text { cannot be ignored }\end{array}$ & $\begin{array}{l}\text { Insistence on making a } \\
\text { claim commonplace on } \\
\text { platforms }\end{array}$ \\
\hline Stance of the scholar & Antagonistic stance & Antagonistic stance & Cooperative stance \\
\hline
\end{tabular}

Table 2 moves from two basic assumptions that: (1) knowledge claims that profess to be decolonised should possess sufficient rigour to be classified as scholarly knowledge; and (2) knowledge claims that profess to further the decolonisation agenda are decolonised claims.

Moving from these assumptions, Table 2 presents a quick reference of the most salient points expounded upon in the discussion above. One point to take cognisance of in Table 2 refers to the stance that the scholar should take as the subject of the emancipatory struggle of knowledge claims. In terms of asserting equality, and creating dissensus, scholars need to assume an antagonistic, uncompromising stance. Necessary, as the individual scholar, as the champion of these knowledge claims, needs to assure that the sensible as 
a system reaches a point where these claims can no longer be ignored. If this stance is not assumed, the likelihood exists that the scholars' effort will diminish and eventually disappear as the sensible constantly pushes back through efforts to marginalise and ignore these claims. Only once the sensible as a system has acknowledged these claims, can the scholar as champion change their stance to be more cooperative, as the sensible gets reconfigured through engagement.

\section{Conclusion}

This article has shown that parallels exist between decolonisation as an intellectual project and CMS. From this, one can conclude that decolonisation is a form of critical scholarship and can potentially benefit from principles applied in other areas of critical inquiry. To this end, denaturalisation was proposed as a vehicle through which decolonisation can be sought. However, in the absence of a normative of pragmatic discourse on denaturalisation, Jacques Rancière's emancipation ideas can act as guiding principles to denaturalise mainstream management thinking with the eye on decolonising the discourse.

However, it needs to be acknowledged that denaturalising along the proposed lines to move towards a decolonised management curriculum is not a quick process, nor is it likely to occur in huge strides. On the contrary, when dealing with issues such as decolonisation, one has to acknowledge that this is likely to entail much effort with very little initial return, that it will take a long time before the system of the sensible is reconfigured sufficiently, and that 'progress' will imply very small incremental advancements. Conversely, decolonisation cannot be left to evolve organically, nor should it be left to other authorities (such as governments or university management committees) to determine what guise decolonisation in the management discourse in South Africa will assume. The onus is on the academics, the South African management scholars themselves to forge their destiny, and to be part of the conversation, irrespective of how uncomfortable, difficult, and time-consuming, it might be.

\section{References}

Adler, P.S., Forbes, L.C. \& Willmott, H. (2007). Critical Management Studies. In: J.P. Walsh \& A.P. Brief (Eds.). The Academy of Management Annals Vol. 1. Mahwah, NJ: Lawrence Erlbaum. 119-179. https://doi. org/10.5465/078559808

Alvesson, M. \& Willmott, H. (2003). Studying Management Critically. London: Sage.

Banerjee, S.B. \& Linstead, S. (2001). Globalization, Multiculturalism and Other Fictions: Colonialism for the New Millennium? Organization, 8(4):683-722. https://doi.org/10.1177/135050840184006

Blauner, R. (1964). Alienation and Freedom: The Factory Worker and His Industry. Chicago, III: University of Chicago Press.

Bridgman, T. \& Stephens, M. (2008). Institutionalizing Critique: A Problem of Critical Management Studies. Ephemera: Theory \& Politics in Organization, 8(3):258-270.

Butler, N. \& Spoelstra, S. (2014). The Regime of Excellence and the Erosion of Ethos in Critical Management Studies. British Journal of Management, 25(1):538-550. https://doi.org/10.1111/1467-8551.12053 
Calás, M. \& Smircich, L. (2006). From 'The Woman's' Point of View Ten Years Later: Towards a Feminist Organization Studies. In: S. Clegg, C. Hardy, T. Lawrence \& W. Nord (Eds.). The Sage Handbook of Organization Studies. London: Sage. 84-346. https://doi.org/10.4135/9781848608030.n9

Collini, S. (2012). What Are Universities For? London: Penguin.

Costas, J. \& Fleming, P. (2009). Beyond dis-identification: A discursive approach to alienation in contemporary corporations. Human Relations, 62(3):353-378. https://doi.org/10.1177/0018726708101041

Denzin, N.K. (2010). Moments, Mixed Methods and Paradigm Dialogs. Qualitative Inquiry, 16(6):419-427. https://doi.org/10.1177/1077800410364608

Disemelo, K. (2015). Student protests are about much more than just \#FeesMustFall. Mail \& Guardian, 29 October. https://bit.ly/2LrBZ6r [Accessed 28 April 2020].

Dryzek, J.S. (2002). Deliberative Democracy and Beyond: Liberals, Critics, Contestations. London: Oxford University Press. https://doi.org/10.1093/019925043X.001.0001

Fanon, F. (1963). The Wretched of the Earth. New York: Grove Press.

Fomunyam, K.G. (2017a). Decolonising the Engineering Curriculum in a South African University of Technology. International Journal of Applied Engineering Research, 12(17):6797-6805.

Fomunyam, K.G. (2017b). Decolonising the Future in the Untransformed Present in South African Higher Education. Perspectives in Education, 35(2):168-180. https://doi.org/10.18820/2519593X/pie.v35i2.13

Fournier, V., and Grey, C. (2000). At the Critical Moment: Conditions and Prospects for Critical Management Studies. Human Relations, 53(1):7-32. https://doi.org/10.1177/0018726700531002

Garuba, H. (2015). What is an African curriculum? Mail \& Guardian, 17 April. http://mg.co.za/article/2015-0417-what-is-an-africancurriculum/ [Accessed 10 March 2020].

Goldman, G.A., Nienaber, H. \& Pretorius, M. (2015). The essence of the contemporary business organisation: a critical reflection. Journal of Global Business and Technology, 12(2):1-13.

Goldman, G.A. (2016a). Multiparadigmatic, cooperative opportunities for the study of business management. Management Dynamics, 25(3):2-15.

Goldman, G.A. (2016b). On the possibility of fostering critical management studies in South Africa. In: G.A Goldman (Ed.). Critical Management Studies in the South African context. Cape Town: AOSIS. 3-30. https://doi.org/10.4102/aosis.2016.cmssac08

Gordon, R.A. \& Howell, J.E. (1959). Higher education for business. New York: University of Columbia Press. https://doi.org/10.7312/gord91408

Govender, P., Heyneke, D., Mntambo, R. \& Goldman, G.A. (2018). Decolonisation of the curriculum: progress in an academic department at the University of Johannesburg. Paper presented at the annual International Business Conference (IBC), Mauritius, 23-26 September.

Grey, C. \& Willmott, H. (2005). Critical Management Studies: A Reader. London: Oxford University Press.

Heleta, S. (2016). Decolonisation of higher education: Dismantling epistemic violence and Eurocentrism in South Africa. Transformation in Higher Education, 1(1):1-8. https://doi.org/10.4102/the.v1i1.9

Huault, I., Perret, V. \& Spicer, A. (2014). Beyond macro- and micro-emancipation: rethinking emancipation in organization studies. Organization, 21(1):22-49. https://doi.org/10.1177/1350508412461292

Jack, G. \& Westwood, R. (2006). Postcolonialism and the politics of qualitative research in international business. Management International Review, 46(4):481-501. https://doi.org/10.1007/s11575-006-0102-x

Johnson, P. \& Duberley, J. (2003). Reflexivity in Management Research. Journal of Management Studies, 40(5):1279-1303. https://doi.org/10.1111/1467-6486.00380

Knight, J. \& Goldman, G.A. (2016). Decolonisation of the Curriculum: A South African Reality. Paper presented at the annual GBATA Conference, Dubai, UAE, 16-20 October.

Langdon, J. (2013). Decolonising development studies: Reflections on critical pedagogies in action. Canadian Journal of Development Studies, 34(3):384-399. https://doi.org/10.1080/02255189.2013.825205

Le Grange, L. (2016). Decolonising the University Curriculum. South African Journal of Higher Education, 30(2):1-12. https://doi.org/10.20853/30-2-709 
Linstead, S., Maréchal, G. \& Griffin, R.W. (2014). Theorizing and Researching the Dark Side of Organization. Organization Studies, 35(2):165-188. https://doi.org/10.1177/0170840613515402

Maserumule, M.H. (2015). Why Africa's professors are afraid of colonial education being dismantled. The Conversation, 25 November. https://bit.ly/3a13le0 [Accessed 30 November 2015].

Mbembe, A. (2015). Decolonizing Knowledge and the Question of the Archive. Johannesburg: Wits Institute for Social and Economic Research. https://bit.ly/2KaA1H5 [Accessed 9 March 2020].

Mentz, J.C., Kotzé, P. \& Van Der Merwe, A. (2008). Searching for the Technology in Universities of Technology. South African Computing Journal, 42(1):29-37.

Mgqwashu, E. (2016). Universities can't decolonise the curriculum without defining it first. The Conversation, 16 August. https://bit.ly/37WeQ3s [Accessed 12 April 2020]

Muswede, T. (2017). Colonial legacies and the decolonisation discourse in post-apartheid South Africa: A reflective analysis of student activism in Higher Education. African journal of public affairs, 9(5):200-210.

Ngugı wa Thiong'o. (2004). Decolonizing the Mind. The Politics of Language in African Literature. Nairobi, Kenia: East African Educational Publishers.

Nkomo, S.M. (2011). A postcolonial and anti-colonial reading of 'African' leadership and management in organization studies: tensions, contradictions and possibilities. Organization, 18(3):365-386. https://doi. org/10.1177/1350508411398731

Nwadeyi, L. (2016). We all have a responsibility to disrupt the status quo. Mail \& Guardian, 29 June. https:// bit.ly/2W421i4 [Accessed 30 June 2016].

Pierson, F.C. (1959). The education of American businessmen: A study of university college programs in business administration. New York: McGraw-Hill.

Pillay, S. (2015). Decolonizing the University. The Frantz Fanon Blog, 9 June. https://bit.ly/2W5psHM [Accessed 10 March 2020].

Prasad, A. \& Mills, A.J. (2011). Critical Management Studies and Business Ethics: A Synthesis and Three Research Trajectories for the Coming Decade. Journal of Business Ethics, 94(1):227-237. https://doi. org/10.1007/s10551-011-0753-9

Prinsloo, E.H. (2016). The role of the Humanities in decolonising the academy. Arts \& Humanities in Higher Education, 15(1):164-168. https://doi.org/10.1177/1474022215613608

Rahlaga, M. (2015). 'No punishment planned' for protesting WITS students. EWN, 17 October. https://bit.ly/ 3m2oHK5 [Accessed 23 August 2018].

Rancière, J. (1987). Le maître ignorant, Cinq leçons sur l'émancipation intellectuelle. Amsterdam, The Netherlands: Galilee.

Rancière, J. (1995). La mésentente. Amsterdam, The Netherlands: Galilee.

Rancière, J. (1998). Aux bords du politique. Paris: La Fabrique.

Rancière, J. (2004). The politics of aesthetics: the distribution of the sensible. London: Continuum.

Rancière, J. (2006). La méthode de l'égalité. In: L. Cornu \& P. Vermeren (Eds.). La philosophie déplacée. Bourgen-Bresse, France: Horlieu Editions. 507-523.

Rancière, J. (2009a). Et tant pis pour les gens fatigués. Entretiens. Paris: La Fabrique

Rancière, J. (2009b). Moments politiques. Interventions 1977-1999. Paris: La Fabrique

Ruby, C. (2009). L'interruption. Jacques Rancière et la politique. Paris: La Fabrique.

Terrell, S.R. (2012). Mixed-Methods Research Methodologies. The Qualitative Report, 17(1):254-280.

Sułkowski, L. (2019). On Bullshit Management - The Critical Management Studies Perspective. Economics and Sociology, 12(1):302-312. https://doi.org/10.14254/2071-789X.2019/12-1/18

Wren, D.A. \& Bedeian, A.G. (2009). The Evolution of Management Thought. Hoboken, NJ: John Wiley \& Sons.

Zembaylas, M. (2018). Decolonial possibilities in South African Higher Education: Reconfiguring humanising pedagogies as/with decolonising pedagogies. South African Journal of Education, 38(4):1-11. https://doi. org/10.15700/saje.v38n4a1699 